\title{
Investigation of the Effectiveness of Scientific Research Methods Course in Terms of Academic Dishonesty Tendencies
}

\author{
Selin (Inag) Çenberci \\ Department of Mathematics and Science Education, Ahmet Kelesoglu Education Faculty, Necmettin Erbakan University, Turkey
}

Copyright(C2018 by authors, all rights reserved. Authors agree that this article remains permanently open access under the terms of the Creative Commons Attribution License 4.0 International License

\begin{abstract}
The need to create awareness and consciousness in the universities and educational faculties that train the teacher trainees has been met with the Scientific Research Methods courses, which deals with the ethical and especially scientific and publication ethics aspects of Academic Dishonesty Behaviors because of their frequent occurrence. In this study, it was aimed to examine the Academic Dishonesty Tendency scores of mathematics teacher trainees, who took Scientific Research Methods courses and who did not take these courses. In addition to this it was determined whether these tendencies differ significantly in terms of gender variable. The sample of the research was composed of Mathematics teacher trainees who were studying in the Department of Mathematics Education of a State University. This study is a descriptive study, which was carried out using the general scanning model. The "Academic Dishonesty Tendency Scale" (ADTS) was used to determine the academic dishonesty tendencies of the Mathematics teacher trainees. As the result of this study, it was determined that academic dishonesty tendencies of the Mathematics teacher trainees, both who took and did not take Scientific Research Methods courses, were at the medium level.
\end{abstract}

Keywords Mathematics teacher trainees, Academic Dishonesty Tendency

\section{Introduction}

Since our behaviors in daily life and academic life are closely related to "ethical values", it is also very important to make individuals gain ethical values throughout their educations. The development of a country depends on the ethical ideas and moral behaviors of the individuals. This is also possible through education; one of the main purposes of education is to raise the right, proper and honest people in [3]. The effects of the present behaviors of individuals on their future behaviors are also an undeniable fact. This fact reveals the importance of this subject in every stage of the education. In our century, the effects of universities on the education of decent, ethically behaving and qualified individuals, who are able to respond to the requirements of this era, are very important. This is because of the fact that the universities are the last place for individuals to gain or shape these ethical values before they start their careers. Students will decide by taking the basic values they have acquired into consideration and according to their personality structures, when they come to the decision-making positions after this last formatting in the university. Therefore, universities have a very important place in all world countries. Especially considering that the students who will graduate from the Education Faculties of universities are the future teachers who will raise new generations, the importance of the Education Faculties has been increasing. Turkey Academy of Sciences [35], based on the concept of ethics, it defines a moral life in which individuals can differentiate between right and wrong, and defines them as a field for revealing the right behavior. Ethics is defined as the standards that individuals who perform a particular occupation must comply with. While ethical behavior in terms of academic research appears with cheating at the beginning of the education life, it is generally referred to as academic dishonesty in universities and it is seen as a concept that includes sub-dimensions in addition to cheating. Academic dishonesty is used not only in individuals' educational lives, but also at all stages of their professional life. Academic dishonesty has become a tendency that became prevalent among university students with the development of technology over the last years in $[2,23]$.

Academic dishonesty is defined as the unethical behavior that the individuals exhibit, when testing their own knowledge [19]. Aluede and others [1] define academic dishonesty, cheating in academic duty, making a copy in the exam, making changes in homework, changing exam papers, cheating in academic duty, plagiarism. 
Another definition is given as the students' such as behaviors in the form of cheating to increase their academic success levels or in the direction of their interests, copying the homework and plagiarizing in [21]. Ozden and Ergin [28] emphasized in their study that ethical rules have a very important place in conducting studies in accordance with scientific criteria of individuals, who start both undergraduate and postgraduate educations, in order to conduct scientific research. Cheating, which is one of the academic dishonesty behaviors, is defined as the unethical behavior that the students demonstrate during the examination for themselves or their friends to gain academic success in [26]. Eminoglu [11] stated that cheating is not only cheating on exams, but also another dimension is cheating on home works. The part regarding the cheating on homework leads us to the concept of plagiarism. In the Turkish Dictionary, [35] plagiarism is defined as 'pilferage'. As the result, it is a sad fact that the students both cheating and plagiarizing are exhibiting an immoral behavior. Park [24] categorized the students' plagiarism behaviors as; only one students' declaring that a study, which was prepared by multiple individuals, belongs to only himself/herself and use that study, using the same or very similar studies for different courses, copying another work without properly citing or writing the same statements in different sentences, and using a study owned by someone without his/her permission.

In addition, a number of studies have been carried out in the field of academic dishonesty, and whether there is a relationship between certain variables and academic dishonesty tendencies has been investigated. In the study of Buyukgoze [6], it was stated that there is a negative relationship in the moderate level for the pre-service teachers between their self-sufficiency levels and academic dishonesty tendencies. In addition, the results of the study conclude that academic dishonesty tendencies are at a low level and overall self-sufficiency is at a moderate level. In addition to this, the fear of being subject to a negative evaluation is thought to be another reason for academic dishonesty tendencies and [25], examined the relationship between the fear of being subject to a negative evaluation and the academic dishonesty tendencies in pre-service teachers in the Education Faculty of a State University, concluded that there was a low level of relationship between the sub-dimensions of academic dishonesty tendencies and the fear of being evaluated negatively. In their study in 2018, Kiral and Saracaloglu [17] examined the relationship between Academic Dishonesty Tendency and fear of being evaluated negatively, and concluded that there was a low level and significant relationship between the tendency of academic dishonesty and fear of being subject to a negative evaluation, in a way supporting the abovementioned study. In their study in [4], investigated the relationship between the basic values of pre-service primary school teachers and academic dishonesty tendencies, and it was shown that there were positive and significant relationships with certain sub-basic values, as well as the negative and significant relationships with other sub-basic values. Certel, Bahadir, Saracaloglu and Varol [9] examined the relationship between the tendency of pre-service physical education teachers and academic achievement perception, depending on gender, the status of performing physical exercises variables, to cheat and in addition to this they revealed the relationship between the tendency to cheat and the academic control focus. According to the results of the study, there was a low level of relationship between the pre-service teachers' tendency to cheat and external-internal academic control focus. In the study of [16] it was aimed to examine academic dishonesty tendencies and values of pre-service teachers and it was found that there was a significant difference between the academic dishonesty tendencies and values of the pre-service teachers, according to the gender variable.

Considering all of this, the question of what causes the tendency towards this academic dishonesty comes to the forefront. Kibler [18] emphasized that it is difficult to determine the reasons for the students' resorting to academic dishonesty. As the result of the studies, higher note requires, anxiety depending on the time, acceptance of cheating as a normal behavior, importance given to friendly relationships, pressure of friends, fear of failure, lack of knowledge, anxiety about the grades are presented as some of the reasons for the students to resort to academic dishonesty in $[13,15,31]$ In each stage of the training course, the content of the assignments to the students and emphasizes that students will be made to how the transfer of citations, is one of the most important in this training [30]. Detection of these is of great importance in the elimination of academic dishonesty tendencies. In their study, Ozden, Ozdemir Ozden and Bicer [27] aimed to determine the views of pre-service teachers on academic frauds. As the result of the study, they emphasized that one of the most frequent academic fraud behaviors was allowing another student to see the exam paper. In their study, Ersoy and Ozden [13] emphasized that the lecturers who attached importance to whether the homework was done increase the tendency of university students to use the previously prepared homework papers, which are on the web. Another study stated that males tend to be more prone to academic dishonesty than females in [10], [20]. Ozden and Ergin [28] conducted a research with three students who completed their graduate studies in order to determine their views on ethical rules applied in scientific research. As a result of the study, it was stated that graduate students behaved in accordance with ethical rules applied in scientific research in their studies.

It is observed that some of the pre-service teachers who have different perspectives on academic dishonesty tendencies are not aware of the importance and consequences of these behaviors. With the Ministry of National Education starting to re-prepare the curriculum according to the constructivist approach and starting to 
implement the new curriculums for the 1-5 grades of primary education, in the academic year 2004-2005, it became very important for the students to acquire the research culture. Finally, with the studies of the Council of Higher Education in 2006, the Education Faculties were reorganized and arrangements have been made for courses to be taught. With this arrangement, the weight was given to general culture courses and one of these courses was Scientific Research Methods Course and put among the compulsory courses taught in all teaching departments [37]. With this course of 2 credits, it is aimed to create awareness on the subjects such as basic concepts of science (facts, information, universal knowledge, ethics, scientific and publishing ethics), the structure of scientific research, methods used in science, universe, sampling, and data collection techniques. This course, which is given under the names as Scientific Research Methods in undergraduate education and Scientific Research Techniques and Ethics in the graduate education, discusses what scientific studies are and how they are done in terms of content and covers the ethical and scientific ethical issues. In the books of [7] "Fundamentals of Scientific Research", the subjects of "ethics, scientific ethics and publishing ethics" are included. In order to raise the awareness of pre-service teachers about this subject, ethical issues are also included in the Scientific Research Methods course. The need to raise awareness has emerged because of the fact that the behaviors in daily life and academic life are closely related to the "ethical values". Increasing productivity and quality in the profession depends on understanding the importance of professional ethics. In addition to this, it is inevitable that the tendencies towards academic dishonesty behaviors that individuals gain and demonstrate in the educational process will affect their professional lives $[11,22,14]$. In order for the students who graduate from the university to be introduced to their business life with this awareness and competence and to act accordingly, they awareness should be raised and they should be educated in these matters through these courses in their undergraduate education. Therefore, the attitudes of the university students, who will raise the new generations, against academic dishonesty are of great importance. Students who are educated regarding the importance and consciousness of the subject are avoiding such negative behaviors in their professional lives and the situations of tolerating such behaviors are eliminated. For this purpose, when the contribution of this study in the Education Faculties is taken into account, it is thought that this research is a unique study in determining the Academic Dishonesty Tendencies of the students and taking the necessary precautions by determining the reasons regardless of their branch.

When all the above mentioned facts are considered, in this study, it was aimed to investigate the Academic Dishonesty Tendency scores of the Mathematics teacher trainees who took and who did not take the Scientific
Research Methods course, whether these tendencies differ significantly according to the gender variable and whether there is a significant difference between them according to the variable of taking the course. For this purpose, "Investigation of the Effectiveness of Scientific Research Methods Course in terms of Academic Dishonesty Tendencies" was determined as the problem sentence. In this context, the following sub-problems have been tried to be answered.

1. What is the level of academic dishonesty tendencies for the Mathematics teacher trainees who take and do not take the Scientific Research Methods courses?

2. Is there a significant difference between the academic dishonesty tendencies of the Mathematics teacher trainees who take or do not take the Scientific Research Methods courses?

3. Do the Mathematics teacher trainees who were taking the course of Scientific Research Methods Course the academic dishonesty tendencies of vary according to the gender?

\section{Materials and Methods}

This research aims to determine the effectiveness of the Scientific Research Methods course in terms of ethics. The research is a descriptive study as it will be tried to determine the current situation and in the study, the general screening model, which is among the screening models, was used [33]. In addition, Academic Dishonesty Tendency scores of Mathematics teacher trainees who took Scientific Research Methods course were compared in terms of gender variable. With this aspect, this research is also a comparison study [5].

\subsection{Universe and Sample}

The universe of the study is constituted of the Mathematics teacher trainees, who were studying at the Education Faculty of a state university during the Fall Semester of the 2017-2018 Academic Year. Since it was not possible to reach the entire universe in the existing conditions, a sample selection was made and a total of 322 Mathematics teacher trainees, 210 of whom took the Scientific Research Methods course and 112 of whom did not take it, completed the questionnaire as directed.

\subsection{Data Collection Tool}

The 'Academic Dishonesty Tendency Scale - ADTS' developed by Eminoglu [11], [12] was used to determine the academic dishonesty tendencies of the participants. The 5-point Likert type scale consists of 22 items. There are nine reverse-coded items on the scale. The scale consists of the sub-dimensions of 'tendency of cheating (1)', 'dishonesty tendency in studies such as homework 
and projects (2)', 'dishonesty tendency in the process of research and reporting (3)' and 'dishonesty tendency regarding the citations (4)'. The original Cronbach alpha value of the scale was reported as .90. Cronbach Alpha reliability coefficient for all of the scales in this study was calculated as 87 . The data on the applied scale was analyzed using the data rating scale. There are five options on the scale. The range coefficients for four ranges $(5-1=4)$ on the five-point scale are $0.80(4 / 5)$. The values between 1-1.79 were very low, the values between 1.80 and 2.59 were low, the values between 2.60 and 3.39 were medium, the values between 3.40 and 4.19 were good and the values between 4.20 and 5 were very good.

\subsection{Data Analysis}

In the study, statistical techniques were used to analyze data; frequency, percentage mean, standard deviation and significance tests were performed. The mean and standard deviation values of the mathematics teacher trainees' scores regarding Academic Dishonesty Tendency were determined.

Table 1 was established to determine whether there was a significant difference between the Mathematics teacher trainees' trends according to the gender variable. According to the data presented in Table 1, Mann-Whitney $U$ test was used for data not showing normal distribution [8].

\section{Findings}

In this section, in order to examine the effectiveness of scientific research methods in terms of Academic Dishonesty Tendencies, the findings obtained from this study on Mathematics teacher trainees are given in line with the sub-problems.

\subsection{The First Sub-problem}

The first sub-problem sentence of the study is in the form of "What is the level of academic dishonesty tendencies for the Mathematics teacher trainees who take and do not take the Scientific Research Methods courses?” In order to answer this problem, descriptive statistics were analyzed and the score averages and standard deviation values of the Mathematics teacher trainees who took and did not take the courses in accordance with the sub-dimensions of "Cheating tendency", "dishonesty tendency in studies such as homework and projects", "dishonesty tendency in the process of research and reporting", "dishonesty tendency regarding the citations", and "total Academic Dishonesty Tendency" are presented in Table 2.

Table 1. Normality test data on the scores of the Mathematics teacher trainees who took and did not take the course of Scientific Research Methods

\begin{tabular}{cccccccc}
\hline & \multicolumn{3}{c}{ Kolmogorov-Smirnov $^{\mathrm{a}}$} & \multicolumn{3}{c}{ Shapiro-Wilk } \\
\cline { 2 - 6 } & Statistic & $\mathrm{df}$ & Sig. & Statistic & $\mathrm{df}$ & Sig. \\
\hline Cheating tendency & .100 & 322 & .000 & .965 & 322 & .000 \\
\hline Dishonesty tendency in studies such as homework and projects & .142 & 322 & .000 & .929 & 322 & .000 \\
\hline Dishonesty tendency in the process of research and reporting & .173 & 322 & .000 & .953 & 322 & .000 \\
\hline Dishonesty tendency regarding the citations & .133 & 322 & .000 & .965 & 322 & .000 \\
\hline Academic Dishonesty Tendency & .116 & 322 & .000 & .910 & 322 & .000 \\
\hline
\end{tabular}

Table 2. Descriptive statistics data on the Academic Dishonesty Tendency scores of the Mathematics teacher trainees who took and did not take the course of Scientific Research Methods

\begin{tabular}{|c|c|c|c|c|}
\hline & Factors & $\mathbf{n}$ & $\mathbf{X}$ & SS \\
\hline \multirow{5}{*}{$\begin{array}{l}\text { Mathematics teacher } \\
\text { trainees who took the } \\
\text { course }\end{array}$} & Cheating tendency & 210 & 3.0530 & .68821 \\
\hline & $\begin{array}{l}\text { Dishonesty tendency in studies such as homework } \\
\text { and projects }\end{array}$ & 210 & 2.9558 & 60001 \\
\hline & Dishonesty tendency in the process of research and reporting & 210 & 2.3214 & .62419 \\
\hline & Dishonesty tendency regarding the citations & 210 & 3.0437 & 62303 \\
\hline & Academic Dishonesty Tendency & 210 & 2.8435 & .47500 \\
\hline \multirow{5}{*}{$\begin{array}{l}\text { Mathematics teacher } \\
\text { trainees who did not take } \\
\text { the course }\end{array}$} & Cheating tendency & 112 & 3.0112 & .76992 \\
\hline & $\begin{array}{l}\text { Dishonesty tendency in } \\
\text { studies such as homework and projects }\end{array}$ & 112 & 2.8036 & 68529 \\
\hline & $\begin{array}{l}\text { Dishonesty tendency } \\
\text { in the process of research and reporting }\end{array}$ & 112 & 2.1897 & 44042 \\
\hline & Dishonesty tendency regarding the citations & 112 & 2.8363 & .60693 \\
\hline & Academic Dishonesty Tendency & 112 & 2.7102 & 49204 \\
\hline
\end{tabular}


The average of "Academic Dishonesty Tendency" score of Mathematics teacher trainees who took scientific research methods course was 2.84. The "Cheating tendency" was highest with the sub-dimension mean score of 3.05 , and the "dishonesty tendency in the process of research and reporting" was lowest with the sub-dimension mean score 2.32. Since the Academic Dishonesty Tendency score average of the Mathematics teacher trainees who took the course corresponds to the 2.60-3.39, we can say that the Mathematics teacher trainees' academic dishonesty tendencies are at a moderate level.

The average of "Academic Dishonesty Tendency" score of Mathematics teacher trainees who did not take Scientific Research Methods course was 2.71. The mean score of the "cheating tendency" (3.01) was the highest and the "dishonesty tendency in the process of research and reporting" subscale mean score (2.18) was the lowest. Since the Academic Dishonesty Tendency score average of the Mathematics teacher trainees who did not take the course was between 2.60 and 3.39, we can say that the Mathematics teacher trainees' Academic Dishonesty Tendencies were at the moderate level because the evaluation scale corresponds to the values between 2.60 and 3.39.

It is noteworthy that the Academic Dishonesty Tendency means scores of the Mathematics teacher trainees, who took and did not take Scientific Research Methods course, were close to each other, although it was higher for those who did not take the course.

\subsection{The Second Sub-problem}

The second sub-problem sentence of the study is in the form of "Is there a significant difference between the academic dishonesty tendencies of the Mathematics teacher trainees who take or do not take the Scientific Research Methods courses?" This can be expressed as "There is a significant difference between Academic Dishonesty Tendency score averages of Mathematics teacher trainees who took and did not take Scientific Research Methods courses".

To test this hypothesis, the data that did not show a normal distribution, and the data of Academic Dishonesty Tendency scores of the Mathematics teacher trainees obtained as the result of the Mann-Whitney $U$ test are given in Table 3.

Table 3. Mann-Whitney U test results on the Academic Dishonesty Tendency scores of the Mathematics teacher trainees who took and did not take the course of Scientific Research Methods

\begin{tabular}{|c|c|c|c|c|c|c|}
\hline Factor & $\begin{array}{c}\text { The status of taking } \\
\text { the course }\end{array}$ & $\mathbf{N}$ & $\begin{array}{c}\text { Mean } \\
\text { rank }\end{array}$ & Rank sum & Mann-Whitney U & $\mathbf{p}$ \\
\hline \multirow{2}{*}{ Cheating tendency } & Did not take & 112 & 159.19 & 17829.50 & \multirow{2}{*}{11501.500} & \multirow{2}{*}{$\begin{array}{l}.05 \\
59\end{array}$} \\
\hline & Took & 210 & 162.73 & 34173.50 & & \\
\hline \multirow{2}{*}{$\begin{array}{c}\text { Dishonesty tendency in } \\
\text { studies such as homework and } \\
\text { projects }\end{array}$} & Did not take & 112 & 150.48 & 16854.00 & \multirow{2}{*}{10526.000} & \multirow{2}{*}{$\begin{array}{c}.00 \\
5\end{array}$} \\
\hline & Took & 210 & 167.38 & 35149.00 & & \\
\hline \multirow{2}{*}{$\begin{array}{c}\text { Dishonesty tendency in the process } \\
\text { of research and reporting }\end{array}$} & Did not take & 112 & 150.37 & 16841.50 & \multirow{2}{*}{10513.500} & \multirow{2}{*}{$\begin{array}{c}.11 \\
2\end{array}$} \\
\hline & Took & 210 & 167.44 & 35161.50 & & \\
\hline \multirow{2}{*}{$\begin{array}{l}\text { Dishonesty tendency regarding } \\
\text { the citations }\end{array}$} & Did not take & 112 & 141.54 & 15852.00 & \multirow{2}{*}{9524.000} & \multirow{2}{*}{$\begin{array}{c}.11 \\
9\end{array}$} \\
\hline & Took & 210 & 172.15 & 36151.00 & & \\
\hline \multirow{2}{*}{ Academic Dishonesty Tendency } & Did not take & 112 & 148.10 & 16587.50 & \multirow{2}{*}{10259.500} & \multirow{2}{*}{$\begin{array}{c}.74 \\
5\end{array}$} \\
\hline & Took & 210 & 168.65 & 35415.50 & & \\
\hline
\end{tabular}

According to the variable of taking the courses, there was a significant difference in the mean score of Academic Dishonesty Tendency of the Mathematics teacher trainees, only in the sub-dimension of "Dishonesty tendency in studies such as homework and projects". There was no significant difference in the sub-dimensions of "Cheating tendency", "dishonesty tendency in studies such as homework and projects", "dishonesty tendency in the process of research and reporting", "dishonesty tendency regarding the citations", and "total Academic Dishonesty Tendency". When the mean ranks are examined, the Academic Dishonesty Tendency score in all sub-dimensions is higher in favor of the Mathematics teacher trainees that took the course. It can be expressed that the difference between the other averages except for the sub-dimension of "Dishonesty tendency in studies such as homework and projects" is not significant; the Academic Dishonesty Tendency of the Mathematics teacher trainees who took the course is higher.

\subsection{The Third Sub-problem}

The third sub-problem sentence of the study is in the form of "Do the Mathematics teacher trainees who were taking the course of Scientific Research Methods Course the academic dishonesty tendencies of vary according to the gender?". It can also be expressed as follows: "Is there a significant difference between the Academic Dishonesty Tendency scores of the female and male Mathematics teacher trainees in Mathematics Teaching." 
To test this hypothesis, the data that did not show a normal distribution, and the data of Academic Dishonesty Tendency scores of the Mathematics teacher trainees obtained as the result of the Mann-Whitney U test are given in Table 4.

Table 4. Mann-Whitney U test results on the Academic Dishonesty Tendency scores of the Mathematics teacher trainees who took the course of Scientific Research Methods according to the gender variable

\begin{tabular}{|c|c|c|c|c|c|c|}
\hline Factor & Gender & $\mathbf{N}$ & Mean rank & Rank sum & Mann-whitney U & $\mathbf{p}$ \\
\hline \multirow{2}{*}{ Cheating tendency } & Female & 138 & 103.12 & 14230.00 & \multirow{2}{*}{4639.000} & \multirow{2}{*}{.429} \\
\hline & Male & 72 & 110.07 & 7925.00 & & \\
\hline \multirow{2}{*}{$\begin{array}{c}\text { Dishonesty tendency } \\
\text { in studies such as } \\
\text { homework and } \\
\text { projects }\end{array}$} & Female & 210 & 104.94 & 14481.50 & \multirow[b]{2}{*}{4890.500} & \multirow[b]{2}{*}{.852} \\
\hline & Male & 138 & 106.58 & 7673.50 & & \\
\hline \multirow{2}{*}{$\begin{array}{l}\text { Dishonesty tendency } \\
\text { in the process of } \\
\text { research and reporting }\end{array}$} & Female & 72 & 105.32 & 14534.50 & \multirow{2}{*}{4943.500} & \multirow{2}{*}{.953} \\
\hline & Male & 210 & 105.84 & 7620.50 & & \\
\hline \multirow{2}{*}{$\begin{array}{l}\text { Dishonesty tendency } \\
\text { regarding the citations }\end{array}$} & Female & 138 & 104.24 & 14385.50 & \multirow{2}{*}{4794.500} & \multirow{2}{*}{.676} \\
\hline & Male & 72 & 107.91 & 7769.50 & & \\
\hline \multirow{2}{*}{$\begin{array}{c}\text { Academic Dishonesty } \\
\text { Tendency }\end{array}$} & Female & 210 & 103.49 & 14281.00 & \multirow{2}{*}{4690.000} & \multirow{2}{*}{.506} \\
\hline & Male & 138 & 109.36 & 7874.00 & & \\
\hline
\end{tabular}

According to the gender variable, there was no significant difference in the sub-dimensions of "Cheating tendency", "dishonesty tendency in studies such as homework and projects", "dishonesty tendency in the process of research and reporting", "dishonesty tendency regarding the citations", and "total Academic Dishonesty Tendency" in the Academic Dishonesty Tendency mean scores of Mathematics teacher trainees. When the mean score was examined, the Academic Dishonesty Tendency score in all sub-dimensions is slightly higher in favor of male Mathematics teacher trainees. It can be expressed that Academic Dishonesty Tendency is not related to being male or female considering the fact that the difference between the averages is not significant.

\section{Discussion and Conclusion}

It was determined that "Academic dishonesty tendencies" was at a moderate level for both the Mathematics teacher trainees who took and did not take the Scientific Research Methods course. [25] and [17] also found that the academic dishonesty tendencies were at a moderate level. This shows that the findings of our study overlap with the findings of these two studies. It is important that the total average scores of the Academic Dishonesty Tendencies of the Mathematics teacher trainees, who took and did not take the Scientific Research Methods course, were found to be high in favor of those who did not take the course, although they were at a medium level in both groups and very close to each other. We can interpret this in the way that Mathematics teacher trainees who did not take the course show more academic dishonesty behavior than those who took the courses. The fact that the Mathematics teacher trainees who take the lessons abide by the ethical rules more is an indication that the Scientific Research Methods course contributed to the avoidance of Mathematics teacher trainees ' Academic Dishonesty Behaviors. A conflicting situation with our study comes to the forefront in the study of Buyukgoze [6] who found that the academic dishonesty tendencies of the pre-service teachers are at a low level. Similarly, the Mathematics teacher trainees who took and did not take the course had the highest scores in "Cheating tendency" sub-dimension, and lowest scores in "dishonesty tendency in the process of research and reporting" sub-dimension. The fact that cheating tendency is the sub-dimension with the highest score indicates an alarm situation starting from primary education. When assessed in general terms, the moderate levels of academic dishonesty tendencies in Mathematics teacher trainees who took this course can be due to not mentioning the ethics extensively within the scope of the course, and however, for all Mathematics teacher trainees, the only course in the Faculty of Education that includes the subject of ethics is the course of Scientific Research Methods.

It was found that there was a significant difference in the "dishonesty tendency in the process of research and reporting" sub-dimension among the Academic Dishonesty Tendency mean scores of the Mathematics teacher trainees. This difference is in favor of the Mathematics teacher trainees who took the scientific research methods course. This means that the Mathematics teacher trainees who took the course were more likely to Academic Dishonesty Tendency in studies such as homework and projects than those who did not take the course and that the reason for the increase in this tendency may be interpreted to be caused by the facts that the homework and projects are evaluated within the same environment and individuals have the perturbation of a negative evaluation. It can be said that except for the "dishonesty tendency in studies such as homework and 
projects" sub-dimension the tendency of academic dishonesty is higher in the Mathematics teacher trainees who took the courses, although the difference between the other averages is not significant. According to the gender variable, there was no significant difference between the Academic Dishonesty Tendency mean scores of the Mathematics teacher trainees, who took the Scientific Research Methods course in Mathematics Education Department. It can be expressed that Academic Dishonesty Tendency is not related to being a male or female Mathematics teacher trainees, considering the fact that the difference between the averages is insignificant. When the rank average scores were examined, it was seen that the Academic Dishonesty Tendency scores were higher in all sub-dimensions in favor of male Mathematics teacher trainees, even though there was only a slight difference. In the study conducted by Unlu and Eroglu [32] there was no significant difference in terms of gender variable. This study supports the results of our study. In a study conducted by Kadi, Baytekin and Arslan [16], it was found that there was a significant difference between the academic dishonesty tendencies of Mathematics teacher trainees according to the gender variable. According to the certain results that do not overlap with our study, Roig and Caso [29], found higher academic dishonesty tendencies for male Mathematics teacher trainees compared to females while in [36] found that the male pre-service teachers had higher academic dishonesty tendencies than females and [25] reached the conclusion that male Mathematics teacher trainees tend to have a higher level of tendency towards dishonesty in research and reporting dimension than female Mathematics teacher trainees. As a result of their study, [17] found that there was a significant difference related to gender variables in the dimensions of dishonesty tendency in studies such as homework and projects and the citations. They determined that the average of male Mathematics teacher trainees' opinions was high in these dimensions. In the dimension of dishonesty tendency during the process of conducting research and reporting, it was found that the views of female Mathematics teacher trainees were different from the views of male Mathematics teacher trainees.

\section{Suggestions}

In the of Scientific Research Methods course, the ethical issues should be emphasized by the lecturers more comprehensively, and the subject should be focused by mentioning it in every course and each homework, and the importance of avoiding the academic dishonesty behavior should be stressed.

A new course can be added to the undergraduate curriculum, to provide detailed information only on the types and sub-dimensions of academic dishonesty.

Mathematics teacher trainees should be informed about the penalties that will be imposed as a result of plagiarism.
It should especially be emphasized that they should spend effort to prevent cheating tendency, which start and continue in the early stages of education and training life, taking into account the sensitivity of this situation

Mathematics teacher trainees should be ensured to attend the student symposiums in order to eliminate academic dishonesty tendencies in their homework and projects presentations and should be encouraged to make numerous presentations by explaining them about what they need to pay attention.

\section{REFERENCES}

[1] Aluede, O., Omoregie, E. O. \& Osa-Edoh ,G. I. (2006). Academic dishonesty as a contemporary problem in higher education: how academic advisers can help. ERIC No: EJ765511.

[2] Arslantas, C. C., Acar, G. Perceptions of academic and business dishonesty among senior level students, Yonetim, Vol.19, No.60, 34-49, 2008.

[3] Baysen, F., Baysen, E., Cakmak, N. The Effect of International Baccalaureate Program on High School Students' Misconceptions Regarding Plagiarism. Bilgi Dunyas1, Vol.18, No.1, 1-20, 2017.

[4] Belet Boyaci, S.D., Babadag, G., Guner, M. Examınation of Basic Values and Academic Dishonesty Tendencies of Pre-Service Elementary Teachers. Abant Izzet Baysal University Journal of Education Faculty, Vol.17, No.4, 1762-1793, 2017.

[5] Beyhan, O. Student Perceptions on the Teaching Styles of Their Teachers, Hacettepe University Journal of Education, Vol. 34, 2018. doi: 10.16986/HUJE.2018036946

[6] Buyukoze. Ogretmen Adaylarinin Akademik Sahtekarlik Egilimlerinde Ozyeterlik ve Akademik Kontrol Odaginin Rolu, Manisa Celal Bayar Universitesi Sosyal Bilimler Dergisi, Vol.15, No.1, 801-822, 2017.

[7] Buyukozturk, S., Kilıc Cakmak, E., Akgun, O.E., Karadeniz, S., Demirel, F. (2010). Bilimsel Arastırma Yontemleri. Ankara: Pegem Publications.

[8] Can, A. (2013). SPSS ile Bilimsel arastirma surecinde Nicel Veri Analizi. Ankara: Pegem Academy.

[9] Certel, Z., Bahadir, Z., Saracaloglu, S., Varol, R. The Investigaton of Physical Education Teacher Candidates' Attıtudestowards Cheating and Their Academic Control Focus, Vol. 6, No.2, 259-271, 2017.

[10] De Sumrak, N., Tobin, J. (2014). Academic cheating among youths: A causal pathway model. Poster presentation retrieved from http://www.docstubo.net/45615480/Academic-cheating-pd f/ on April 10, 2016.

[11] Eminoglu, E. (2008). Universite Ogrencilerinin Akademik Sahtekarlik Egilimlerinin Olculmesine Yonelik Bir Olcek Gelistirme Calismasi. Msc Thesis, Abant Izzet Baysal University, Bolu. 
[12] Eminoglu, E., Nartgun, Z. A scale development study to measure Academic Dishonesty Tendency of university students. Journal of Human Sciences, Vol. 6, No.1, 215-240, 2009.

[13] Ersoy, A., Ozden, M. The views of teacher candidates regarding the role of instructor in plagiarizing from Internet in their assignments. Ilkogretim Online, Vol.10 No.2, 608-619, 2011.

[14] Graves, S. M. Student cheating habits: A predictor of workplace deviance. Journal of Diversity Management-First Quarter, Vol. 3, No. 1, 14-22, 2008. Retrived from http://www.cluteinstitute.com/ojs/index. php/JDM/article/view/4977/5069.

[15] Gumusgul, O., Ustun N, U. D., Isik U., Demirel, D. H. Beden Egitimi ve Spor Yuksekokulu Ogrencilerinin Akademik Sahtekarlik Egilim Duzeylerinin Degerlendirilmesi, Ankara Univ Spor Bil Fak, Vol. 11 No.2, 131-138, 2013.

[16] Kadi A., Beytekin O. F., Arslan H. Academic Dishonesty Tendencies and Values of Teacher Candidates, Journal of Higher Education and Science, Vol. 6, No. 3, 396-401, 2013.

[17] Kiral B. ve Saracaloglu S. The Relationship between Academic Dishonesty Tendency and Fear of Negative Evaluation, YYU Journal of Education Faculty, Vol. 15, No.1, 323-359, 2018.

[18] Kibler, W.C. Academic dishonesty: A student developmental dilemma. NAPSA Journal, Vol. 30, 252-267, 1993.

[19] Kucuktepe, S. E. Evaluation of tendency towards academic dishonesty levels of psychological counseling and guidance undergraduate students. Procedia Social and Behavioral Sciences, Vol. 15, 2722-2727, 2011.

[20] Kucuktepe, C., Kucuktepe, E. S. The Analysıs Of Cheatıng Behaviours Of The College Students According To The Students' Perspectıves, Vol 3,No. 3, 263-270, 2014.

[21] Lin, C., Wen, L. Academic dishonesty in higher education-a nationwide study in Taiwan. Higher Education, Vol. 54, 85-97, 2007.

[22] Memduhoglu, H. B., Tayiz, V. (2016). Egitim Fakultesi ogrencilerinin akademik sahtekârlik egilimlerinin degerlendirilmesi. 15. Uluslararasi Sinif Ogretmenligi Egitimi Sempozyumu Tam Metin Bildiriler Kitabi icinde (s.629- 639). Mugla: Mugla Sitki Kocman University Publication.

[23] Murdock, T. B., Anderman, E. M. Motivational perspectives on student cheating: Toward an integrated model of academic dishonesty. Educational Psychologist, Vol. 41, No.3, 129-145, 2006.
[24] Park, C. In other (people's) words: Plagiarism by university students - literature and lessons. Assessment \& Evaluation in Higher Education, Vol. 28, No.5, 471-488, 2003. doi: $10.1080 / 02602930301677$.

[25] Omur, Y. E., Aydin, R., Argon, T. Relationship between Prospective Teachers' Fear of Negative Evaluation and Their Academic Dishonesty Tendencies. Journal of Education and Humanities: Theory and Practice, Vol.5,No.9, 131-149, 2014.

[26] Ozden, M., Ozdemir Ozden, D. Defining Academic Dishonesty Behaviors According to Pre-Service Teachers. Journal of Higher Education and Science, Vol.5, No.1, 88 98, 2015. DOI: 10.5961/jhes.2015.112

[27] Ozden, M., Ozdemir Ozden, D., Bicer B. Academic Dishonesty: The Views and Experiences of Teacher Candidates, Mersin University Journal of the Faculty of Education, Vol. 11, No.2, 505-525, 2015.

[28] Ozden M., Ergin B. Determination of Postgraduate Students' Views About Ethical Rules Applied To Scientific Researches. Mustafa Kemal University Journal of Social Sciences Institute. Vol.10, No. 22, 155-169, 2013.

[29] Roig, M., Caso, M. Lying and cheating: fraudulent excuse making, cheating, and plagiarism. The Journal of Psychology, Vol. 139, No.6, 485-494, 2005.

[30] Ucak, N. O., Birinci, H.G. Scientific ethics and plagiarism, Turk Kutuphaneciligi, Vol.22, No.2, 187-204, 2008.

[31] Ucak, N.O. Ogrencilerin intihal algisi. Prof. Dr. K. Gulbun Baydur`a Armagan icinde (s.173-182). Ankara: Hacettepe Universitesi Bilgi ve Belge Yonetimi Bolumu, 2012.

[32] Unlu, H., Eroglu C. Prospective Physical Education Teachers' Attitudes Towards Cheating, Spormetre Beden Egitimi ve Spor Bilimleri Dergisi, X Vol.3, 101-106, 2012.

[33] Sonmez, V., Alacapinar, F. Orneklendirilmis Bilimsel Arastırma Yontemleri. Ankara: Ani Publication, 2011.

[34] Turk Dil Kurumu, Turkce sozluk http://www.tdk.gov.tr

[35] Turkiye Bilimler Akademisi Bilim Etigi Komitesi. (2002). Bilimsel arastırmada etik ve sorunlar. Ankara: Turkiye Bilimler Akademisi Publications.

[36] Yangin, S. Attitudes and ideas of candidate primary school teachers towards copying. Balıkesir University the Journal of Social Sciences Enstitute, Vol. 12, No. 21, 46- 55, 2009.

[37] YOK, Council of Higher Education, Education faculty teacher training undergraduate program, 2007. http://www.yok.gov.tr/documents/10279/30217/EİTIM+F AKÜLTESİ\%20ÖĞRETMEN+YETISTTIRME+LISANS+ PROGRAMLARI.pdf/054dfc9e-a753-42e6-a8ad-674180d 6e382. 